\title{
A Qualitative Research on University Students' Religious Approaches during the Grieving Process
}

\author{
Elif Kara ${ }^{1}$ \\ Mus Alparslan University
}

\begin{abstract}
The main objective of this research is to examine university students' grieving process after the death of a relative in the context of their religious approaches. The working group of the study is composed of 15 participants who were determined from the Education, Science-Literature and Theology Faculties of Muş Alparslan University using the criterion sampling method. The study has a phenomenological design. A semi-structured interview form has been used as the data collection tool. Data obtained from the interviews have been subjected to content analysis. Accordingly, students' emotions and behaviors are first concluded to change as a result of their closeness to the relative lost; in the case of losing a closer relative, such as a mother, father, or sibling, negative feelings like anger and rebellion are more dominant. Secondly, although students believe in God, life after death, and heaven, they have been determined to need spiritual support when adapting to loss and rearranging their life. In the study's results, the necessity for developing and implementing spiritual care and counseling is discussed.
\end{abstract}

Keywords

Loss $\bullet$ Loss of a loved one $\bullet$ Grief $\bullet$ Mourning $\bullet$ Religious coping $\bullet$ Spiritual care

\section{Üniversite Öğrencilerinin Yas Sürecindeki Dini Yaklaşımları Üzerine Nitel Bir Çalışma}

$\ddot{\mathrm{O} z}$

Bu araştırmanın temel amacı üniversite ögrencilerinin yakınlarının ölümleri sonrasında yaşadıkları yas sürecini dini yaklaşımları bağlamında incelemektir. Araştırmanın çalışma grubunu Muş Alparslan Üniversitesindeki üç farklı fakülteden (Eğitim, Fen-Edebiyat ve İlahiyat) ölçüt örnekleme yoluyla belirlenen 15 katılımcı oluşturmaktadır. Çalışma fenomenoloji desenindedir. Veri toplama aracı olarak yarı yapılandırılmış görüşme formu kullanılmıştır. Araştırma sonunda elde edilen veriler içerik analizine tabi tutulmuştur. Buna göre ilk olarak, öğrencilerin kayıplarının yakınlığına göre duygu ve davranışlarının değiştiği, özellikle de anne-baba-kardeş gibi daha yakın kayıplarda isyan ve öfke gibi olumsuz duyguların baskın olduğu sonucuna varılmıştır. İkinci olarak ise araştırmaya katılan öğrenciler Allah'a inanç, ölüm ve ötesine inanç, cennete inanç gibi temel inançlara sahip olmakla birlikte, kayba uyum ve yaşamı yeniden düzenlemekte manevi desteğe ihtiyaç duydukları tespit edilmiştir. Bu çalışma neticesinde ögrencilerin yas süreçlerine yönelik "manevi bakım/danışmanlık" geliştirilmesi ve uygulanmasının gerekliliği tartışılmıştır.

\section{Anahtar Kelimeler}

Kayıp • Sevilen birinin kaybı • Yas • Matem • Dini başa çıkma • Manevi bakım

1 Correspondence to: Elif Kara, Department of Educational Sciences, Mus Alparslan University, Mus Turkey. Email: eliffkara28@gmail.com

Citation: Kara, E. (2017). A qualitative research on university students' religious approaches during the grieving process. Spiritual Psychology and Counseling, 2, 203-223. http://dx.doi.org/10.12738/spc.2017.2.0029 
In a broad sense, grieving describes the deeply distressing period experienced after a loss. It is important to evaluate what the concept of loss contains before examining the grieving process. In literature, loss includes losing anything that seems important and meaningful to an individual. In other words loss not only indicates the absence of a loved one, but also covers many circumstances like the loss of a business, property, materials, or status and loss of relationships like divorce or separation (Worden, 2009). In order for one to continue life in good health, one must accept, experience, and complete the mourning period. The individual in mourning will learn to live life by accepting loss as a part of life (Worden, 2009, 2001). Most people find it difficult to return to their daily routines after the death of a close relative and may not want to go to work to meet simple needs like eating and sleeping. Grievers should rearrange their relationship with the deceased by organizing emotional thought behaviors during the upset and adjusting to the loss. The griever should continue living by accepting the changed position of the lost in one's life.

Many studies have examined the difficult process from the moment of loss to adaptation and the phases experienced during this. The most important of these studies belongs to Kübler-Ross (1997/1969). In her book Death and Dying, KüblerRoss researched her five-stage model related to death. According to her research, the five basic stages of the grieving process are: (a) Denial: It is faced when the negative news is received. It is when loss is not accepted and reactions like "there must be a mistake, this cannot happen to me" are observed. This first phase, when it is important for the individual to save time adapting, is a protective response the organism demonstrates in order to adjust to the traumatic situation. (b) Anger: After facing the reality of loss, this stage is where reasons for the loss are wondered about and questioned; the individual feels anger towards the self and possibly feels responsible. (c) Bargaining: This stage is where the individual desperately hopes for a miracle development, hoping to change the sad truth being faced. (d) Depression: This period is when one accepts being helpless in the face of the negative situation; the pain is really experienced. (e) Acceptance: With the acceptance of truth, this stage is when one questions what should be done, and life is reorganized. These phases are hierarchical and follow each other, but sometimes with the passing of time features like deep sadness, crying, and anger can suddenly return (Kübler-Ross, 1997/1969). Although individual reactions may differ in these phases (i.e., one griever may cry while another seeks solitude), common physical, cognitive, emotional, and behavioral reactions are observed in individuals during grieving (Parkes, 1998, pp. 856-859). The following reactions may appear after the death of a relative:

Physical reactions. These are reactions such as emptiness in the stomach, dry mouth, weakness, crying, and a feeling of drowning (Toth, Stockton, \& Browne, 2000). 
Cognitive reactions. These include shock, refusing to believe the relative died, not focusing on a subject or work, numbness, difficulty making decisions, and excessive preoccupation with the lost one (Worden, 2009).

Emotional reactions. Confusion, sadness, anger, guilt, anxiety, helplessness, exhaustion, numbness, relief (especially when the deceased had suffered greatly), hallucinations, loneliness, and longing (Balk, 2011) are the emotional signs related with mourning. Because feeling angry toward the deceased for having passed away may be disturbing, anger can be diverted toward one's environment (Worden, 2009). Another destructive feeling that can be observed in individuals who've lost a relative is guilt. This feeling is particularly common in people who think they were not sufficiently interested in the deceased or hadn't fulfilled their responsibilities. Likewise, the relatives of those who died from a long, exhausting, and severe illness may blame themselves for feeling relieved when the person dies (Worden, 2009).

Behavioral reactions. These are generally observed as sleeping disorders, refraining from social environments, excessive mobility, continuously visiting places that remind one of the deceased, carrying the deceased's belongings, unable to continue an organized event, or acting irrationally (Balk, 2011; Corr, 1999). In some studies undertaken on the grieving process in university students, decreases in academic success and abstention from social activities are seen (Fajgenbaum, 2007, p. 101; Hardison, Neimeyer, \& Lichstein, 2005; Neimeyer, Laurie, Mehta, Hardison, \& Currier, 2008, p. 37).

\section{Religious Beliefs and Factors Affecting Adaptation to Loss in the Grieving Period}

Losing a close relative is an inevitable phenomenon, and the sadness that follows loss changes a person. Humankind tends to constantly redefine life and reorganize the world in one's mind (Wadsworth, 2015, pp. 21-32). Traumatic events in particular cause people to redefine their lives. Many studies have examined the factors effective on leaving sorrow behind after a death to reorganize one's life. Some important factors have been determined to influence the grieving process for coping with death. These factors are the degree of closeness to the deceased, the nature of the relationship, the way the deceased passed, whether or not one receives social support, past losses, and how one copes using beliefs and values (Worden, 2009, 2001).

The need to find meaning in events is richly met with religious beliefs. Researchers have expressed the importance that having an understanding of mourning at the beginning of the grieving period has as a factor positively affecting the process (Balk, 2008; Neimeyer \& Anderson, 2002; Tyson-Rawson, 1996). Again, some studies have found the factor of religious belief to be helpful during mourning (Frantz, Trolley, \& Johil, 1996). Balk's (2010) study on students arrived at the finding that religious answers can be useful for the need to find meaning (Balk, 2010). 
In general, both religious believers' beliefs after death and participation in religious rituals help explain death during the grieving process, and a meaningful relationship was found between the ability to explain death and having low levels of depression (Matthews \& Marwit, 2004).

Religion can contribute positively to the griever by providing death with meaning. However, some studies have shown that religious belief has also been used to make negative statements. Pargament, Koenig, and Perez (2000), examining the forms for finding religious meaning, defined the positive and negative effects of faith on people. In his study, he developed a "positive religious coping" and a "negative religious coping" model by evaluating peoples' religious explanations of traumatic events. If a person shows religious behavior toward a sad experienced event as "I pray to escape the problem," then belief can help overcome the stress caused by negative events. If the explanation contains negative meanings, such as "I doubt God loves me," this kind of religious faith leads to more sadness and stress (Pargament, 2000).

Ayten's (2012) study on religion in the context of Islam stated that the understanding of a vengeful God negatively affects mental health, while understanding God as merciful and evaluating events as based on God's will and love can contribute positively to mental health (Ayten, 2012, pp. 70-81). In the Islamic literature, many concepts exist for positive coping, such as patience, gratitude, resignation, seeking refuge in God, and not abandoning hope in God. Religious references that can be applied during grieving can help find meaning by cognitively presenting a causeand-effect relationship. In this way, the mourner can find emotional relief. Here are some verses that can help one in the phases of finding meaning in death, coping, and acceptance: "Muhammad was no more than a messenger, like the messengers before him. Should he die or be killed, would you turn back on your heels?" (Qur'an 3:144). In this passage, one is reminded that the Prophet is also mortal.

You will surely be tested in your possessions and in yourselves. And you will surely hear much abuse from those who were given the Scripture before you and from those who associate others with Allah. But if you are patient and fear Allah - indeed, that is of the matters [worthy] of determination. (Qur'an 3:186)

Being a Muslim does not prevent one's suffering. However, Islam is the way of welcoming suffering, cognitively guiding one in organizing the mind.

The religion of Islam has many explanations about life and death. Muslims believe that death is only for the body; the spirit is eternal, and the purpose for creating mankind is to recognize and try to understand God during the span of life one is granted. According to Islam, people in this world are tried with many positive and negative events in order to reach spiritual maturity. The idea of trial helps to give meaning to 
events. El-İsfahani, in his masterpiece Müfredat (translated by Güneş \& Yolcu, 2012, p. 778), explained this trial as " ...throwing gold into the fire to separate the pure from the corrupt." Here, the metaphor of fire can be used to extract the beauties inside a human, and one is tested by being faced with pain through maturity. Some of the many verses regarding the tests of man are as follows: "....We saved you from retaliation and tried you with a (severe) trial" (Qur'an 20:40). "Every soul will taste death. And we test you with evil and with good as a trial; and to us you will be returned" (Qur'an 21:35).

As seen in these verses, death according to Islamic sources is not final; the relatives of the deceased are tested while the deceased is sent to the afterlife. Within the scope of verses, the phrases generally used in the tradition of Muslim populations after one has died also involve this understanding. They are talked about with positive phrases such as "passed over to the afterlife," "connected with the eternal life," "walked to God," "went to kingdom-come," "rest in heaven," "it is the will of God," and "God have mercy on them." The deceased is not actually the one who died, nor has the deceased diminished; one is sent to eternity with the hope of reaching the afterlife. The pain felt after one has died is caused by the loss of the relationship; one can no longer do what they had been done before together. One can no longer spend time with the deceased. In order to cope with death, one can be provided with the coping characteristics of religious belief through appropriate guidance.

Some studies have indicated the positive effect of religion on coping with death to exist through the meaning it provides. One research on students indicated that loss may positively contribute to students' personality development and that the mourning period can become positive (Gilliges \& Neimeyer, 2006; Neimeyer, 2004). For this, having a student be provided with proper guidance is important (Fajgenbaum, 2007). Again, some research among university students has found the opposite: Students were found to have cognitive issues. Among them were observed confusion about God's characteristics, whether they are good, bad, or cruel, and being afraid to share this thought (Burke \& Neimeyer, 2014). On this point, the need can be discussed for the fields of secular and religious counseling to regulate the complex reactions and emotions in the grieving process.

\section{Spiritual Counseling/Care and Coping with the Grieving Period}

The objectives of counseling (depending on the principles and approaches of the institution) include support for crises intervention and management; decision making; symptom alleviation; insight and empowerment; remediation; self-actualization; personality exchange; exploration of meaning and transcendental experience; systematic, institutional, or social change; introspection; cognitive change; full functioning; personal development; perspective development; and intentionality (Ok, 2014). Spiritual counseling has three main dimensions: healing, support, and guidance (Koç, 2012). 
Religious counseling has emerged to be a form of psychological counseling shaped by counselor's affinity for the broadest values and meanings that consider religious/spiritual issues seriously (Ok, 2014). Spiritual counselors use religious motifs in reference to the sacred in addition to the psychological methods of their studied field (Koç, 2012, p. 204). The realization of psychological healing depends on the therapist's ability to understand the worldview. In this interaction, an empathic communication between the therapist and counselee helps the counselee give meaning to the events being faced (Özdoğan, 2006).

Spiritual care already involves guidance and seems to indicate a less individual and more humanistic structure in this assistive relationship; this is more comprehensive than guidance. The final objective of counseling and care services is to have the individual fully exercise their humanity (Ok, 2014). Although the theoretical subdivisions of psychology and theology differ from one another, each has the common goal of having the individual achieve emotional balance (Özdoğan, 2005). Spirituality contributes to a person's mental health, to responding to personal quests, and to making sense of life (Hökelekli, 2015). Psychological sources and methods have gradually been used in the field of spiritual counseling and guidance (Ekşi, Kaya, \& Çiftçi, 2016).

Grief counseling for students, being well researched, is an area of service that has many examples in the world. Balk (2010) determined that students need counselors to talk about and explore negative thoughts; $43.6 \%$ of students who had lost a relative were determined to state the helpfulness of talking about the loss, while $42.8 \%$ defined this as a little helpful. A study suggesting that spiritual crises can provide positive development has drawn attention to how experiencing loss at a young age can and should be part of one's personality and maturation process (Lord \& Gramling, 2012). Grief counseling is not a new field in Turkey; studies exist on how to provide grief counseling to students (Genç \& Aydın, 2015, Gizir, 2006, Şenelmiş, 2006; Zara, 2011).

Studies on spiritual grief counseling have tried to expose the need for grief counseling using spiritual values (Kara, 2016a; Yaman, 2016). Işık (2016) defended the necessity of spiritual counseling for families in the process of grieving after having lost a baby. Kara (2016b) suggested a grief counseling model for the feeling of loss experienced by families with disabilities. However, studies in this area are still new. Although the first valuable studies have been undertaken with people of Islamic beliefs, they are few and no model has been developed yet regarding how to implement grief counseling.

Following the death of a loved one, spiritual counseling was assessed for individuals with relatives in need of support; religion has also been assessed in terms of its use for coping with the many cognitive, emotional, and behavioral experiences felt during the 
mourning period. As seen, both positive and negative aspects of religious behavior during mourning have been found in field research. One important problem is that those grieving can make their lives even worse with their religious beliefs. In line with this information, this study's aim is to describe the religious feelings, thoughts, and behaviors of students who have lost a relative. This description is based upon previous studies on the grieving process, taking into account the thoughts, feelings, and behavioral characteristics of those who have entered the mourning period after the death of a loved one. These features' dimensions have physical, cognitive, emotional, and behavioral responses to grieving as well as religious cognitive, emotional, and behavioral responses. These dimensions are described in the survey. Students were asked the following basic questions in the study:

1. What did you go through after losing your relative? Can you talk about it?

2. Can you share the religious feelings, thoughts, and behaviors you experienced after your loss?

3. How much time has passed since your loss? What do you think about it now?

\section{Method}

This part of the study contains descriptions of the study group, data collection tool used in the study, data collection process, and data analysis. This research has been carried out using a phenomenological design, a qualitative research type. Phenomenology focuses on a phenomenon that lacks in-depth or detailed knowledge, even though people have experienced and are aware of it. In phenomenology studies, the data analyzes experiences to reveal deep meaning. This research, which addresses the issue with qualitative data collection techniques, uses the semi-structured interview. Researchers mostly prefer semi-structured interviews because they remove the limits observed in tests based on writing, filling out forms, and answering questions; they help the researcher achieve in-depth information on a specific subject (Yıldırım \& Şimşek, 2016).

\section{Study Group}

The study uses criteria sampling, a purposive sampling method, to form the study group. Criterion sampling creates samples of persons, events, objects, or situations with qualities determined in relation to the problem (Büyüköztürk, Çakmak, Akgün, Karadeniz, \& Demirel, 2009). Accordingly, the main criteria chosen by the researcher in selecting the study's participants are to have had a loss, to be Muslim, and to have knowledge on major religious matters such as death in Islam and the hereafter. The study has been performed on students from Muş Alparslan University's Education, Science- 
Literature, and Theology Faculties; opinions from 15 students among the volunteers determined to meet the criteria are considered appropriate and have been detailed. Thus, this study is based on the opinions of 15 students. More detailed demographic and personal information about the participants is summarized in Table 1.

Table 1

Frequencies for Demographic and Personal Information

\begin{tabular}{cc}
\hline Relationship to the deceased person & $\boldsymbol{f}$ \\
\hline Mother & 2 \\
Father & 2 \\
Sibling & 1 \\
Other & 10 \\
\hline Time of loss & $\boldsymbol{f}$ \\
\hline Within the past year & 4 \\
A year or more ago & 11 \\
\hline Faculty & $\boldsymbol{f}$ \\
\hline Theology & 6 \\
Science and Literature & 4 \\
Education & 5 \\
\hline Gender & $\boldsymbol{f}$ \\
\hline Female & 8 \\
Male & 7 \\
\hline Grade & $\boldsymbol{f}$ \\
\hline Freshmen & 15 \\
\hline
\end{tabular}

\section{Data Gathering Tool}

A semi-structured interview form has been used as the data collection tool in the research. Studies on grief counseling in Turkey were examined and opinions taken. Prior to preparing the interview form, I had been providing information on the period of mourning and spiritual counseling for three years in the course classes of Religion Psychology, Educational Psychology, and Social Psychology. In this process, students' religious interpretations, ideas, feelings, and thoughts were discussed. Later on, I was visited and questioned by a student who had lost her father, as well as a few other students who had also suffered losses; as a researcher, I was directed to study in this field in order to meet the requests and questions of students who told me they were having trouble breathing and needed someone to speak with. Taking into consideration the students' thoughts and studies on mourning in the literature, four students were asked the first questions prepared for the interview form. After they answered these questions, the semi-structured interview was formed in the direction of the answers given with simple, understandable language. The interview form has questions about the griever's personal and religious feelings and thoughts. When preparing the interview questions, principles have been taken into account such as being easy to understand and non-directive (Bogdan \& Biklen, 1992). In order to check the appropriateness, clarity, and applicability of these prepared questions, the study was presented to experts from the fields of psychological counseling and 
guidance, two educational sciences.

The following measures have been taken in order to provide the study's validity. (a) Negotiations with qualitative analysis experts were conducted during the research process. (b) Participants were informed that the obtained information would only be used for scientific studies within the framework of the study's objectives. (c) Participants were informed that their identities would remain anonymous. (d) Why the researcher chose this topic and its role in the grieving process were described in detail, and the study was performed in accordance with the research model. (e) Long-term and in-depth data were collected and checked for consistency; the results obtained from the data have been reported in relation to each other and the literature. (f) Attempts have been made to increase the credibility of the research by providing direct quotations from the interviewed students.

Each phase of the research has been explained step by step in order to provide external transferability; participants' characteristics and the environment are also expressed in detail. The obtained results are believed to be transferable to groups or environments with similar characteristics.

\section{Data Collection}

The researcher introduced the interview form to students who knew the topic and wanted to participate because it had been mentioned in class. While explaining the purpose of and questions from the study, students who wanted to participate were told they could bring their written answers or send them by e-mail when they wanted. The main reason for granting time while gathering data in such a way is in consideration of the students' willingness to ponder in solitude the answers to sensitive questions about the grieving process they face.

In addition to this, those who wanted to participate in responding to the questions were given a week, as time constraints on such a sensitive situation can cause students difficulty in focusing on the questions.

\section{Data Analysis}

First the data obtained from the texts and e-mails were gathered, then descriptive analysis and content analysis were used to qualitatively analyze the data. Descriptive analysis is a technique for summarizing and interpreting the obtained data according to pre-determined themes. Analyses are often used directly in order to reflect the views of the interviewed individuals; the obtained results are interpreted within the context of causal relationships (Yıldırım \& Şimşek, 2016). Descriptive analysis was performed under efficacy guidelines: data consolidation, data presentation, conclusion, and validation (Türnüklü \& Ünver, 2000). Content analysis attempts to arrive at 
concepts and relations that can generally explain the obtained data. Themes that can be overlooked using a descriptive approach can be discovered with this method (Y1ldirim \& Şimşek, 2016). When presenting the data, criteria such as being a striking (different opinion), explanatory (convenient for a theme), diverse, or extreme example were taken into consideration for selecting quotes (Ünver, Bümen, \& Başbay, 2010).

Data obtained from the interview forms were first transferred to Microsoft Office and read several times, thus creating the coding for the readings. When creating the themes, the most often mentioned words and their meanings were included, then the codes were gathered to perform descriptive and content analyses for revealing the themes (categories) that form the main sections of the research findings. Some views have been shared directly as quotes while revealing the findings. The students, whose names have not been used due to ethical sensitivities, have beem coded as $\mathrm{K} 1, \mathrm{~K} 2$, $\mathrm{K} 3$, and so on up to $\mathrm{K} 15$.

In this encoding process, students' gender and department were not taken into consideration as these were observed to not have a significant effect on their assessments regarding death. Meanwhile in the process of creating the research's themes and sub-themes, the grieving process was assumed to include certain universal feelings, thoughts, and behaviors. For this reason and as explained previously, the themes supported by universal themes have been chosen because of the similarities between the information given in class and students' own thoughts. For example, the sub-theme of reading from the Quran is absent from the themes in the literature as the Christian culture of religious belief has no tradition for reading for the deceased from a holy book on certain days or nights. This sub-theme has been designed for positive themes that indicate coping with loss. In this context, the themes and sub-themes for this research are shown in Table 2.

Table 2

The Themes and Sub-Themes Resulting from Data Analysis

1 General negative responses in mourning

1.1 Physical (such as crying, feeling exhausted)

1.2 Cognitive (memories constantly emerge, irregularities, inability to focus on/complete works started)

1.3 Emotional (guilt, anger)

1.4 Behavioral (can't wake up, eating disorders; eating too much or too little)

\section{Positive reactions in mourning}

2.1 Physical (starting to eat and drink again)

2.2 Cognitive (thinking the deceased to be in peace)

2.3 Emotional (fulfilling responsibilities towards the deceased)

2.4 Behavioral (visiting the grave, talking about the deceased)

\section{Positive religious reactions experienced during the mourning}

3.1 Cognitive (Belief hereafter; believe in the immortality of the soul; belief that the deceased is in heaven)

3.2 Emotional (patience)

3.3 Behavioral (praying, reading Qur'an, doing good deeds for the deceased, giving charity)

4 Negative religious responses in the grieving process 
4.1 Cognitive (Thinking the world to be unjust, thinking of being a sinner)

4.2 Emotional (Anger towards God)

As shown in Table 2, four themes and their related sub-themes were formed according to the results obtained in the research. In the first theme of general negative responses in mourning, behaviors were determined such as post-loss crying, inability to sustain daily routines, and non-stop thinking. The second main theme has behaviors related to coping with death. Awhile after the first sadness and shock phase, daily life can continue. The third theme, positive religious reactions in the grieving process, is composed of sub-themes such as praying, continuing the charity of the deceased, and undertaking deeds and activities that will acquire merits the deceased one would have wanted. Additionally, the theme of negative religious reactions experienced in the grieving process has negative reactions such as the feeling that something should have been done or that a sin had been committed to deserve this sorrow or feeling of guilt.

\section{Results}

\section{Post-Loss Reactions}

As mentioned in the literature, a traumatic process occurs after loss. The cognitive, emotional, and behavioral responses that students experienced in this process have been identified in this study and will be examined as positive and negative reactions in response to students' answers. The severity of mourning and coping states vary according to loss (proximity, how death occurred, etc.; Worden, 2009, 2001). For this reason, determining negative reactions is important. The participant students' negative reactions during the mourning period such as crying, sleeping disorders, appetite disorders, being unable to engage in anything, and only thinking of the deceased are also supported in a review of the literature. Most students experience these negative reactions, particularly in the days following the loss. Negative reactions must gradually converge over the course of normal mourning, and one must be able to continue daily life activities and learn to live with loss.

Coping with loss means that one who has lost a relative will re-implement behaviors such as sleeping, eating, going to work, talking about the deceased, engaging one's environment, and focusing on problems to be solved (Park \& Halifaxs, 2011; Worden, 2001). In this study, students who find it less difficult to remember memories with the deceased or talk about the incident and who consider grave visits as a duty to the deceased can be considered to be coping positively with loss. In this context, positive responses such as visiting the grave, remembering the memories without worry, talking about the deceased, thinking peacefully, and commemorating with love were identified in the students' responses. Grief's positive and negative effect frequencies are presented in Table 3. 
Table 3

Frequencies of the Positive and Negative Effects of Mourning

\begin{tabular}{lllc}
\hline Positive & $\boldsymbol{f}$ & Negative & $\boldsymbol{f}$ \\
\hline Thinking of the deceased at peace & 15 & Crying & 15 \\
Always remembering the deceased & 12 & Overwhelming thoughts of the deceased & 3 \\
Visiting the grave & 9 & Feeling exhausted & 5 \\
Talking about the deceased with love & 9 & Anger & 4 \\
& & Sleeping disorder & 6 \\
& Unable to finish started tasks & 7 & 4 \\
& Difficulty breathing & 4 \\
& Withdrawn & 5 \\
& Appetite disorders & 3 \\
\hline
\end{tabular}

The frequency distribution of the themes drawn from students' expressions is shown in Table 3. Here the effects of the grieving period are seen separated into positive and negative.

Positive reactions. Five students were shown to think of the deceased as being at peace. In particular, coping was concluded to be easier in cases where the deceased was older and sick. One example is: "My grandfather had lung cancer. His condition was getting worse. His pain was over when he died; he was suffering when he was alive" (K11).

The nine students who visit graves think the soul is immortal and the deceased can see them. Chatting at the grave offers relief, even if it is one-sided. This visit provides peace of mind by considering the deceased's duties to have been fulfilled. This may be helpful in coping with death and avoiding the negative effects of the grieving period.

The 13 students who always remember beautiful memories shared their fond memories of the deceased. For example, they mentioned times spent together in the village taking care of animals, talking, or chatting. Grieving is also the process of coping with and accepting loss. From these students' expressions, coping with the loss of secondary relatives like a grandfather or uncle or the loss of those suffering from a long-term illness seems to be easier. Two students in particular explained that their relative had died because they had been sick. When considered in terms of a cognitive approach, they could cope with loss as they were able to find meaning.

Negative reactions. Of the three students who defined memories as source of sorrow, one had lost her father two months prior to the study, and his death was sudden and unexpected. This student said, "My father called me but I didn't go. I told him I would come in two weeks" (K8) and mentioned that she had subconsciously 
always kept this dialogue alive in her mind. The student felt guilty.

Fifteen participants stated facing with crying. Crying was determined for all students after loss. Students who lost a relative like a grandfather or uncle stated crying finished after the first few weeks, while students who lost a relative like a father or mother said they continue to cry from time to time. Symptoms felt in the initial phase of grieving were stated as sleeping disorders for six students, appetite disorders for five of them, difficulty breathing for four, difficulty focusing for seven, and unable to complete work they've started also for seven. Of the students who had lost a mother or father, four also still faced symptoms such as being unable to finish work they'd started and withdraw into themselves. One student who had lost a mother had stated no longer wanting to see friends just because they would send greetings to the family, especially to mother.

One negative reaction of anger is observed in all students who have lost a mother, father, or sibling. A sample statement related to this situation is: "My brother was young when he died. I thought he was so big. He was 7 years older than me. I had thought he was so big; now I am the age he was when he died. I am 19 years old. My brother should not have died" (K1).

As seen in the findings, positive behaviors are observed when death is accepted and loss coped with. On the other hand, more negative reactions are observed when the death is in the immediate family. A search of the literature supports the relationship between the severity of loss and negative reactions (Worden, 2009, 2001).

\section{Religious Reactions after Loss}

The fact that religious belief can be used both positively and negatively in coping with mourning is given in detail in the study's literature section. The severity of mourning is a variable of positive and negative religious coping, and degree of closeness to the deceased is an important factor in this severity (Park \& Halifaxs, 2011; Worden, 2001). In this study, positive and negative reactions have been observed in accordance with the level of closeness to the deceased. Belief in the afterlife gives one hope of reuniting with the deceased. According to the findings from coping and religious-coping studies that have been undertaken (Pargament et al., 2000), explanations originating from religious beliefs toward traumatic, painful events in life support psychological well-being. Positive religious coping has been determined to positively contribute to personal development and maturation (Lord \& Gramling, 2012; Pargament et al., 2000; Park, 2005).

On the other hand, experiencing a traumatic event, especially the loss of a close relative, causes negative physical, cognitive, and behavioral reactions. People want to 
understand why these sad things happen to them by questioning the reasons for it. As mentioned above, a significant part of theories on meaning and coping involves religious references; this can be positive. But people with faith can also fall into negative thoughts and feelings about the things experienced; they may see God as responsible for the negative events that have happened to them and feel angry towards God. This situation has been evaluated as negative religious coping in the related studies. People who have experienced traumatic events have been revealed able to experience negative religious feelings such as anger towards God (Pargament et al., 2000).

Positive and negative religious coping characteristics have been compiled from the themes and sub-themes obtained from the results of the study's analysis.

Table 4

Frequencies for the Positive and Negative Effects of Religious Belief on Mourning

\begin{tabular}{lcll}
\hline Positive & $\boldsymbol{f}$ & Negative & $\boldsymbol{f}$ \\
\hline Praying & 15 & Confusion (rebelling) & 2 \\
Giving charity & 6 & Feeling guilty/sinful & 2 \\
Reading the Qur'an & 3 & Anger & 1 \\
Visiting the grave & 8 & & \\
Belief in the hereafter & 15 & & \\
\hline
\end{tabular}

Positive religious reactions. Students have been found to most often pray after a loss. The prayers include a wish for the deceased to go to heaven and be happy in the afterlife. Three students who can read the Qur'an pray that the soul of the deceased have their good deeds be accepted and sins -if any- be forgiven. Thoughts related to the afterlife are the beliefs that the deceased (having been a good person) will go to heaven, the deceased is watching from heaven, and they'll be reunited in the afterlife.

The students believe their deceased grandparents can see them from the afterlife and think their elders to be at peace, being able to see what the students study and do for work. These depictions reflect the belief that death is not the end but that we should be patient for we will meet in the afterlife. Six students expressed the theme of giving charity in the name of the deceased, even in small amounts. This is accepted as making the deceased more peaceful in the afterlife. Positive memories such as spending time with a grandparent and being given good advice/recommendations also positively contribute to developing a student's personality and are expressed with feelings like love and respect. One student stated having learned from the grandfather how to read the Qur'an and now was reading for him (K7).

The sub-themes here gather around the immortality of the soul and belief in the afterlife. These support students through positive religious coping. Lord and Gramling's study supports this finding, determining $80.6 \%$ of students to have used positive religious coping by thinking of the deceased as being in heaven (Lord \& Gramling, 2012) 
Negative religious reactions. Positive and negative ways of finding the religious meaning of events are defined in the literature. In this study, students who had lost a mother, father, or siblings were determined to sometimes make negative religious assessments. These thoughts are shaped around rebellion, anger, and guilt. K12 made the noteworthy expression: "My mother will not be by my side anymore. Sometimes I cry, 'Why me? Why did you take my mother, God?' I wonder, 'Is there not any other kind of test?' I sometimes think that."

Students who make negative religious explanations feel angry at God for taking the mother, father, or sibling so early by asking what good is there for them when the parent is no longer present in their life. Again, another student explained the loss of the father dying saying, "I must have committed a sin." They feel guilty before God. In a similar study, Burke and Neimeyer (2014, p. 5) determined that youngsters felt far removed from religious beliefs after losing a relative. Here is one of the quotes: "After I lost my brother, I was no longer interested in whether or not I was a sinner." In summary, negative religious coping can be said to be a factor that makes coping difficult for students, especially those who have lost an immediate family member.

\section{The Relationship of Loss with Time}

Kübler-Ross's (1997/1969) study, which evaluated the phases of mourning, indicated that shock, anger, and denial were observed during the initial phases, but these phases did not follow any hierarchical order; reactions in these first phases might even repeat for some time after according to the condition of the loss. Negative coping through religious belief can be observed in these phases. Reactions to the death of an immediate family member are more traumatic and the grief more severe. In this study, the sadness of students who've lost an immediate family member is seen to be repeated at certain times in one's life. Lord and Gramling's study supports the findings of this study and determined the relationship of grief symptoms' severity with negative religious coping. In order to determine in the current study how and when students who'd lost a relative coped with the loss, the students were asked when they'd experienced the loss (Lord \& Gramling, 2012).

Table 5

Frequencies for Time since Loss

\begin{tabular}{lcl}
\hline Time of loss & $\boldsymbol{F}$ & Type of Loss \\
\hline Within the past year & 4 & (1 mother, 1 father, 2 grandfathers) \\
Over a year ago & 11 & (1 mother, 1 father, 1 brother, 1 uncle, 3 grandfathers, 3 grandmothers, 1 maternal uncle) \\
\hline
\end{tabular}

The students were asked when they'd suffered a loss; four were observed to have suffered a loss within the past year. The other 11 had suffered a loss more than a year ago. The participating students who had lost a mother, father, or sibling managed to cope with continuing their lives. Although not as severe as in the first phase when 
they'd experienced the loss, sometimes at graduations or weddings they would feel the loss deeply again. One student's remarkable expression is as follows:

I had gone with a friend to learn if we'd been accepted into a university. We had both been accepted. My friend called her mother, full of joy. I said, "See you later, dear," and left. I cried so much that day. I didn't want anyone to console me. I wanted my mom to come tell me,

"Don't cry, my daughter." I wanted her to tell me how her little daughter had grown up and been accepted into a university. (K12)

Students stated that life would have been better if their mother, father, or sibling who'd passed were still alive. Even with daily routines, the absence of the immediate family member is constantly felt.

\section{Discussion}

This study examines the emotional thoughts and behaviors of students who have lost a relative, emphasizing that students should be emotionally supported. As previously mentioned, grieving is a process of experiencing many emotional, behavioral, and cognitive processes related to sadness, stress, and adversity that begins as soon as someone learns of the death of a close relative. Grieving is an emotional depression where one loses the desire to look after one's self and perform daily functions. An individual who learns of a relative's death and who experiences normal grieving starts with the reactionary phase of shock, denial, anger, and depression until moving on to the phase of acceptance. According to Kübler-Ross (1997/1969), in order to have a positive life and mental health, one needs to pass through these phases in a normal grieving process and then continue a normal life. In the literature, coping with loss is when one accepts the loss and rearranges life (Kübler-Ross, 1997/1969).

The closeness of the loss, the severity of mourning, how the deceased died, and the spiritual expressions used are important factors that affect coping (Worden, 2009, 2001). Pargament (1997) undertook several studies on how people give meaning to events they face. Religion is effective in providing positive spiritual conditions and in being a source of peace through how it explains traumatic incidents (Ayten, 2012; Ekşi, 2001; Pargament et al., 1994).

On the other hand, negative ways of religious coping were also determined. While evaluating religious coping, Pargament exposed positive and negative styles. A person who has experienced an event and feels the need to pray to God is an example of positive coping. However, one who considers a painful life experience to be punishment from God shows a negative use of religious belief and is an example of negative religious coping (Pargament, 1997). In another study with similar results (Bjorck \& Thurman, 2007), the perception that individuals who frequently 
face traumatic events have of God gradually becomes negative. In other studies on grieving, a relationship was identified between negative coping and loss, which may be the most traumatic incident in an individual's life. When sadness is severe, answers to questions like "Why is this happening to me?" tend to also be negative (Lord \& Gramling, 2012; Park \& Halifaxs, 2011; Worden, 2001).

Students were determined to use both positive and negative religious coping styles. In terms of religion, coping styles related to the loss of a grandfather, uncle, grandmother, or sick relative are also positive. All death is sad, but because death is an expected result of old age and illness, coping with these types of loss takes less time. Positive religious coping is used in the process of coping with these manners of death. These are gathered around positive religious themes such as reuniting in the afterlife, reading the Qur'an for the deceased, performing good deeds in their name, visiting their grave, and praying for them.

Students may use negative religious coping in the case of the death of an immediate family member. Because grieving is particularly more severe in these cases, coping with loss becomes harder. Negative religious explanations are observed in these situations, and expressions like being "angry at God for taking mother so early," and "unable to live life with a father because of my sins" have been determined as negative religious coping. Finding religious meaning has been concluded to be affected by the degree of closeness to the deceased relative. The findings from studies given above on positive and negative coping support this study's findings. Another finding is that positive and negative religious coping can coexist. Students who feel angry at God can also believe they'll be reunited in the afterlife. Anger and hope are felt simultaneously. Another important finding of this study is that losing an immediate family member continues to cause sadness, even with the passage of time. In the literature, Kübler-Ross's (1997/1969) indication that the emotions and thoughts of the griever can return during significant life incidents also supports the findings of this study.

Students have been observed to make religious assessments based on the personality of the deceased rather than on variables such as the student's faculty or age. Although the students have religious knowledge, severe grieving is seen to greatly affect their cognitive processes. On this point, students have been observed to need someone to consult with. Although grief counseling has existed for years in Turkey, studies on spiritual counseling/care are still in their infancy. Attempts to add grief counseling using spiritual meaning to the field are currently underway. In light of these findings, a few points have been determined regarding spiritual counseling that should be taken into account. Spiritual counseling is not about evaluating behaviors or passing judgment in terms of Islamic law. Spiritual counseling is focused on 
emotional solutions and aims to understand negative feelings and thoughts to assist in eliminating them. This point is important because, as determined in this study, people with faith can in some cases use their beliefs negatively. While religious belief can explain life events and provide peace, it can also be a source of stress when negative coping is used (Pargament, 2002).

When evaluating religious knowledge from this significant point of view, this knowledge alone may not be sufficient under the roof of spiritual counseling. The psychology of loss also needs to be known. Having knowledge of the many variables and their effects (i.e., the individual stages of grief) is important. The stage and severity of grief also affect religious thought. This area of study, from theory to implementation, needs much research, both on students and other segments of society.

\section{References}

Ayten, A. (2012). Tanrıya sığınmak: Dini başa çıkma üzerine psiko-sosyal bir araştırma [Refuge in God: A psycho-social research on religious coping]. İstanbul, Turkey : İz yayınc1lık.

Balk, D. E. (2008). Grieving: 22 to 30 percent of all college students [Special Issue]. New Directions for Student Services, 121, 5-14. http:dx.doi.org/10.1002/ss.262

Balk, D. E. (2010). Death, bereavement and college students: A descriptive analysis. Mortality, 2(3), 207-220.

Balk, D. E. (2011). Helping the bereaved college student. New York, NY: Springer Publishing Company.

Bjorck, J. P., \& Thurman, J. W. (2007). Negative life events, patterns of positive and negative religious coping, and psychological functioning. Journal for the scientific study of religion. 46(2), 159-167. http:dx.doi.org/10.1111/j.1468-5906.2007.00348.x

Bogdan, R., \& Biklen, S. K. (1992). Qualitative research for education: An introduction to theory and methods. Boston, MA: Allyn and Bacon.

Burke, L. A., \& Neimeyer R. A. (2014). Spiritual distress in bereavement: Evolution of a research program. Religions, 5(4), 1087-1115. http:dx.doi.org/10.3390/rel5041087

Büyüköztürk, Ş., Çakmak, E. K., Akgün, Ö. E., Karadeniz, Ş., \& Demirel, F. (2009). Bilimsel araştırma yöntemleri [Scientific research methods]. Ankara, Turkey: Pegem Net.

Corr, C. A. (1999). Enhancing the concept of disenfranchised grief. OMEGA - Journal of Death and Dying, 38(1), 1-20.

Ekşi, H. (2001). Başa çıkma, dini başa çıkma ve ruh sağlı̆̆ arasındaki ilişsi üzerine bir araştırma: Eğitim, ilahiyat ve mühendislik fakültesi öğrencilerinin karşılaştırılması [An exploration of the relationship between coping, religious coping and mental health. The comparison of the students of faculties of education, divinity and engineering] (Doctoral Thesis, Uludağ Üniversity Social sciences Institute). Retrieved from file://C:/Users/h.d/Downloads/108983.pdf

Ekşi, H., Kaya, Ç., \& Çiftçi, M. (2016). Maneviyat ve psikolojik danışma [Spiritually and psychological counseling]. In H. Ekşi \& Ç. Kaya (Eds.), Manevi yönelimli psikoterapi ve psikolojik danışma [Spiritually oriented psychotherapy and psychological counseling] (pp. 1328). İstanbul, Turkey: Kaknüs Yayınları. 
El-İsfahani, R. (2012). Müfredat: Kuran kavramlarl sözlüğü [Curriculum: A glossary of Quranic concepts] (A. Güneş \& M. Yolcu, Trans. $3^{\text {rd }}$. ed.). İstanbul, Turkey: Çıra Yayıncılık. Retrieved from https://archive.org/details/MufredatRagipElIsfahani

Fajgenbaum, D. (2007). College student bereavement: Unversity responses, programs and policies, and recommendations for improvement (Honors thesis, School of Nursing and Health Studies, Georgetown University, Washington, DC.). Retrieved from https://repository.library. georgetown.edu/bitstream/handle/10822/550863/etd_david_fajgenbaum.pdf

Frantz, T. T., Trolley, B. C., \& Johil, M. P. (1996). Religious aspects of bereavement. Pastoral Psychology, 44(3), 151-162.

Genç, A., \& Aydın, C. (2015). Uzun süren yas döneminde bütünleyici psikolojik danışma uygulaması: Bir olgu sunumu [Integrative counseling practice in a long-term grief: A case report]. The Journal of Academic Social Science Studies International Journal of Social Science, 33, 491-501.

Gillies, J. \& Neimeyer, R. A. (2006). Loss, grief, and the search for significance: Toward a model of meaning reconstruction in bereavement. Journal of Constructivist Psychology, 19(1), 31-65.

Gizir, C. A. (2006). Bir kayıp sonrasında zorluklar yaşayan üniversite öğrencilerine yönelik bir yas danışmanlığı modeli [A model for bereavement counseling for university students experiencing difficulties after a loss]. Mersin University Journal of the Faculty of Education, 2(2). Retrieved from http://dergipark.ulakbim.gov.tr/mersinefd/article/view/5000002949

Hardison, H. G., Neimeyer, R. A., \& Lichstein, K. L. (2005). Insomnia and complicated grief symptoms in bereaved college students. Behavioral Sleep Medicine, 3, 99-111.

Hökelekli, H. (2015). Gençlik, din ve değerler psikolojisi [The psychology of youth, religion, and values]. İstanbul, Turkey: Değerler Eğitim Merkezi.

Işık, Z. (2016). Bebek kaybı yaşayan ailelere yas sürecinde manevi danışmanlık neden gerekli [Why is spiritual counseling necessary for those who have lost baby]? In A. Ayten, M. Koç, \& N. Tınaz (Eds.), Manevi danışmanlık ve rehberlik teori ve uygulama alanları [Spiritual counseling and guidance theory and application areas] (41-65). İstanbul, Turkey: Dem Yay.

Kara, E. (2016a, November). Engelli ailelerinin yaşadıkları kayıp duygusuyla başa çıkmalarına yönelik manevi danışmanlık: Yas danışmanlığ [Spiritual counseling to help disabled families deal with the loss they experience: Grief counseling]. Paper presented at the First International Disability and Religion Symposium, İstanbul, Turkey.

Kara, E. (2016b). Yas süreci ve dini danışmanlık [The grieving process and religious counseling] [Special Issue]. Dokuz Eylül Üniversitesi İlahiyat Fakültesi Dergisi, 251-270.

Koç, M. (2012). Manevî-[psikolojik] danışmanlık ile ilgili batı'da yapılan bilimsel çalışmaların tarihi ve literatürü (1902-2010) üzerine bir araştırma [A survey on the history and literature of scientific studies in the west (1902-2010) on spiritual (psychological) counseling]. Çukurova Üniversitesi İlahiyat Fakültesi Dergisi, 12(2), 239-276.

Kübler-Ross, E. (1997/1969). Ölüm ve ölmek üzerine [On death and dying] (B. Büyükkal, Trans.). İstanbul, Turkey: Boyner Holding Yayınları.

Lord, B. D., \& Gramling, S. E. (2014). Patterns of religious coping among bereaved college students. Journal of Religion and Health, 53(1), 157-177.

Matthews, L., \& Marwit, S. (2004). Complicated grief and the trend toward cognitive behavioral therapy. Death Studies, 28, 849-863.

Neimeyer, R. A. (2004). Fostering post traumatic growth: A narrative contribution. Psychological 
Inquiry, 15, 53-59.

Neimeyer, R. A., \& Anderson, A. (2002). Meaning reconstruction theory. In N. Thompson (Ed.), Loss and grief: A guide for human service practitioners (pp. 45-64). New York, NY: Palgrave.

Neimeyer, R. A., Laurie, A., Mehta, T., Hardison, H., \& Currier, J. M. (2008). Lessons of loss: Meaning-making in bereaved college students [Special Issue]. New Directions for Student Services: Assisting Bereaved College Students. 121, 27-39. http:/dx.doi.org/10.1002/ss.264

Ok, Ü. (2014). Dini danışmanlık: Tanımı ve tarihi [Religious counseling: Definition and history]. In N. Altaş \& M. Köylü (Eds.), Dini danışmanlık ve din hizmetleri [Religious counseling and religious services] (pp. 34-54). İstanbul, Turkey: Ensar Neşriyat.

Özdoğan, Ö. (2005). Din psikolojisi ve manevi değerler. Süleyman Demirel Üniversitesi İlahiyat Fakültesi Dergisi, 2(15). 159-180.

Özdoğan, Ö. (2006). İnsanı anlamaya yönelik bir yaklaşım pastoral psikoloji [An approach to human understanding: Pastoral psychology]. Ankara Üniversitesi İlahiyat Fakültesi Dergisi, 2, 127-141.

Pargament, K. I. (1997). The psychology of religion and coping: Theory, research, practice. New York, NY: Guilford Press.

Pargament, K. I. (2002). The bitter and the sweet: An evaluation of the costs and benefits of religiousness. Psychological Inquiry, 13, 168-181.

Pargament, K. I., Ishler, K., Dubow, E., Stanik, P., Rouiller, R., \& Crowe, P. (1994). Methods of religious coping with the Gulf war: Cross-sectional and longitudinal analyses. Journal for the Scientific Study of Religion, 33, 347-361.

Pargament, K. I., Koenig, H. G., \& Perez, L. M. (2000). The many methods of religious coping: Development and initial validation of the RCOPE. Journal of Clinical Psychology, 56(4), 519-543.

Park, C. L. (2005). Religion as a meaning-making framework in coping with life stress. Journal of Social Issues, 61, 707-729.

Park, C. L., \& Halifaxs, R. J. (2011). Religion and spirituality in adjusting to bereavement grief as burden, grief as gift. In Grief and bereavement in contemporary society (pp. 363372). Abingdon, Oxonl: Routledge. Retrieved from https://pdfs.semanticscholar.org/c928/ ba572e5b0d5f5f66de4cb424338bb1da3907.pdf

Parkes, C. M. (1998). Coping with loss: Bereavement in adult life. British Medical Journal, 316 (7134), 856-859. Retrieved from https://www.ncbi.nlm.nih.gov/pmc/articles/PMC1112778/

Roberts, K. E. (2016). Grief and bereavement among college students (Master's thesis Abilene Christian University). Retrieved from http://digitalcommons.acu.edu/cgi/viewcontent. cgi? article $=1010 \&$ context $=$ etd

Şenelmiş, H. (2006). Ankara Üniversitesi kriz merkezine başvuran yas olguları üzerine bir çalışma [Descriptive study on facts applied to psychiatric crisis intervention center of Ankara University]. (Master's thesis, Ankara University, Ankara, Turkey)

Toth, P. L., Stockton, R. \& Browne, F. (2000). College student grief and loss. In J. H. Harvey \& E. D. Miller (Eds.), Loss and trauma: General and close relationship perspectives (pp. 237-248). Philadelphia: Brunner-Routledge.

Türnüklü, A., \& Ünver, G. (2000). Eğitim bilim araştırmalarında etkin olarak kullanılabilecek nitel araştırma tekniği: Görüşme [Qualitative research technique that can be used effectively in educational science studies: The interniew]. Kuram ve Uygulamada Eğitim Yönetimi, 24, 543-559.

Tyson-Rawson, K. (1996). Relationship and heritage: Manifestations of ongoing attachment 
following father death. In D. Klass, P. R. Silverman, \& S. Nickman (Eds.), Continuing bonds: New understandings of grief (pp. 125-145). Philadelphia, PA: Taylor \& Francis.

Ünver, G., Bümen, N. T., Başbay, M. (2010). Ortaöğretim alan öğretmenliği tezsiz yüksek lisans derslerine öğretim elemanı bakışı: Ege Üniversitesi örneği [Secondary school area teacher's thesis non-thesis master's program teaching staff's view: Ege University example]. Eğitim ve Bilim Dergisi, 155(35), 6377.

Wadsworth, B. J. (2015). Piaget 'nin duyuşsal ve bilişsel gelişim kuramı [Piaget's theory of affective and cognitive development] (Z. Selçuk, Ed.). Ankara, Turkey: Pegem Akademi Yayıncılık.

Worden, J. W. (2009). Grief counseling and grief therapy: A handbook for the mental health practitioner. Springer.

Worden, J. W. (2001).Children and grief: When a parent dies. Guilford.

Yaman, N. (2017). Yas sürecinde manevi danışmanlık ve rehberlik (MDR) [Spiritual counseling and guidance during mourning process (SCG)] In A. Ayten, (Ed.), Manevi danışmanlık ve rehberlik teori ve uygulama alanları [Spiritual counseling and guidance theory and application areas] İstanbul, Turkey: Dem Yay.

Yıldırım, A., \& Şimşek, H. (2016). Sosyal bilimlerde nitel araştırma yöntemleri [Qualitative research methods in the social sciences] (10th ed.). Ankara, Turkey. Pegem Yayıncılık.

Zara, A. (2011). Kayıplar, yas tepkileri ve yas süreci [Losses, grief reactions and grief process]. İstanbul, Turkey: İmge Yayınları. 